\title{
Aktivitas Antihiperurisemia Ekstrak Etanol Daun Afrika (Vernonia amygdalina Delile.) pada Mencit Putih Galur Swiss Webster yang Diinduksi Melinjo dan Hati Ayam
}

\section{Antihyperuricemic Activity of Ethanol Extract of African Leaf (Vernonia mygdaline Delile.) on Swiss Webster White Mice Induced by Melinjo and Chicken Liver Juice}

\author{
Doni Anshar Nuari ${ }^{1 *}$, Hesti Renggana ${ }^{1}$, Cindra Tri Yuniar ${ }^{2}$, Mentari Novitasari ${ }^{1}$, Asholeha Lulu $^{1}$ \\ ${ }^{1}$ Prodi Farmasi Fakultas MIPA Universitas Garut, Jl. Jati No.42B, Tarogong, Garut, Indonesia \\ ${ }^{2}$ Sekolah Farmasi Institut Teknologi Bandung, Jl. Ganesha No.10, Bandung, Indonesia \\ *E-mail: doni@uniga.ac.id
}

Received: 14 Oktober 2020; Accepted: 14 Januari 2021; Published: 30 Juni 2021

\begin{abstract}
Abstrak
Hiperurisemia adalah suatu kondisi dimana terjadi peningkatan kadar asam urat di dalam darah melebihi batas normal. Daun Afrika (Vernonia amygdalina Delile.) secara empiris digunakan masyarakat untuk pengobatan diabetes, hiperkolesterolemia, demam, hipertensi dan asam urat dengan cara meminum rebusan daun Afrika. Penelitian in vivo ini bertujuan untuk mengetahui aktivitas antihiperurisemia ekstrak etanol daun Afrika pada mencit jantan dengan metode POCT (Point Care of Testing). Penginduksi hiperurisemia yang digunakan adalah kombinasi suspensi melinjo dan jus hati ayam secara oral selama 9 hari berturut-turut dan kadar asam urat diukur pada hari ke 1, 3, 6 dan 9. Hasil penelitian menunjukkan bahwa ekstrak etanol daun Afrika (Vernonia amygdalina Delile.) dosis 100, 200, dan $400 \mathrm{mg} / \mathrm{KgBB}$ memiliki aktivitas antihiperurisemia yang berbeda bermakna terhadap kontrol negatif.
\end{abstract}

Kata Kunci: Anti hiperurisemia, Vernonia amygdalina Delile, POCT

\section{Abstract}

Hyperuricemic is a condition in which uric acid level in blood exceeds its normal level. Empirically, African leaves (Vernonia amygdalina Delile.) were used to treat diabetic, hypercholesterolemic, fever, hypertension and hyperuricemic by drinking boiled water of African leaves. This in vivo study was performed to determine antihyperuricemic activity of ethanolic extract of African leaves on male mice using the POCT (Point of Care Testing) method. Suspension combination of melinjo and chicken liver juice were used as hyperuricemic inductor. It is given orally for consecutive 9 days and the uric acid level were tested on day 1, 3, 6, and 9. The results showed that the ethanolic extract of African leaves (Vernonia amygdalina Delile.) at dosage 100, 200, and $400 \mathrm{mg} / \mathrm{KgBW}$ had a significantly different antihyperuricemic activity against negative control.

Keywords: Antihyperuricemic, Vernonia amygdalina Delile, POCT

\section{PENDAHULUAN}

Pola makan pada masyarakat yang banyak mengandung purin tinggi dapat menyebabkan terjadinya peningkatan kadar asam urat (Tarigan et al., 2012). Asam urat merupakan hasil metabolisme purin. Asam urat dibawa ke ginjal melalui aliran darah untuk dikeluarkan bersama urin. Jika terjadi gangguan eliminasi asam urat melalui ginjal, maka akan menyebabkan menurunnya sekresi asam urat ke tubuli ginjal sehingga terjadi peningkatan kadar asam urat dalam darah (Sinaga et al., 2014). Peningkatan kadar asam urat di dalam darah yang melebihi batas normal disebut hiperurisemia. Hiperurisemia dapat diakibatkan karena produksi asam urat yang berlebih, pengeluaran asam urat yang berkurang atau gabungan dari keduanya (Rakanita et al., 2017). Asam urat diekskresikan oleh ginjal melalui urin. Apabila kadar asam urat berlebih, maka ginjal tidak mampu mengatur kestabilannya sehingga sisa asam urat tidak dibuang melalui urin. Akibatnya, terjadi 
penumpukan kristal asam urat pada jaringan sekitar sendi sehingga menyebabkan rasa nyeri pada daerah tersebut (Sumarmin dan Yuniarti, 2017). Penyakit akibat hiperurisemia dikenal sebagai gout atau penyakit pirai (Tarigan et al., 2012).

Menurut Riset Kesehatan Dasar tahun 2018, prevalensi penyakit sendi berdasarkan diagnosis dokter pada penduduk usia $\geq 15$ tahun berdasarkan provinsi di Indonesia. Provinsi Aceh merupakan provinsi dengan tingkat penyakit sendi tertinggi dengan persentase 13,3\%, sedangkan Sulawesi Barat merupakan provinsi dengan tingkat penyakit sendi terendah yaitu dengan persentase 3,2\%. Berdasarkan jenis kelamin, perempuan dengan persentase 8,5\% dan laki-laki 6,1\% (Kemenkes, 2018). Pengobatan untuk hiperurisemia biasanya menggunakan alopurinol untuk mengurangi kadar asam urat dalam darah. Alopurinol bekerja dengan menghambat aktivitas ksantin oksidase yang mengubah hipoksantin menjadi ksantin dan kemudian akan menjadi asam urat (Djohari dan Rovi, 2015). Namun di samping obat sintetik yang disebutkan, banyak tersedia obat tradisional yang secara empiris terbukti berkhasiat dapat menurunkan kadar asam urat darah (Kritiani et al., 2013).

Pemanfaatan obat tradisional atau jamu di Indonesia pada hakikatnya merupakan bagian dari kebudayaan bangsa Indonesia. Meskipun secara empiris obat tradisional terbukti berkhasiat untuk mengatasi berbagai macam penyakit, tetapi khasiat dan kemampuannya belum banyak dibuktikan secara ilmiah maupun klinis (Muhtadi et al., 2014). Salah satu upaya penggunaan obat secara herbal atau tradisional yang dapat digunakan adalah daun Afrika (Vernonia amygdalina Delile). Berdasarkan hal tersebut, maka perlu dilakukan penelitian untuk melihat aktivitas penghambatan enzim ksantin oksidase ekstrak daun Afrika secara in vivo. Tujuan penelitian ini adalah untuk mengetahui apakah ekstrak etanol daun Afrika memiliki aktivitas anti hiperurisemia secara in vivo pada mencit jantan yang diinduksi melinjo dan jus hati ayam.

\section{METODE PENELITIAN}

Metode penelitian yang dilakukan adalah penelitian eksperimental dengan menggunakan rancangan penelitian acak lengkap yang dilakukan di laboratorium. Penelitian ini terdiri dari beberapa tahapan yaitu penyiapan dan determinasi bahan, pengolahan bahan menjadi simplisia, pemeriksaan karakteristik dan penapisan fitokimia simplisia, pembuatan ekstrak etanol, penapisan fitokimia ekstrak, dan pengujian aktivitas antihiperurisemia ekstrak etanol daun Afrika pada mencit secara in vivo. Uji aktivitas antihiperurisemia secara in vivo merupakan pengujian yang dilakukan untuk mengetahui pengaruh suatu senyawa terhadap penurunan kadar asam urat terhadap hewan uji. Pengujian ini terdiri dari 5 kelompok hewan percobaan yaitu kelompok kontrol negatif diberikan suspensi tragakan $2 \%$, kelompok kontrol positif menggunakan alopurinol dosis $14 \mathrm{mg} / \mathrm{kgBB}$ dan 3 kelompok uji dengan variasi dosis yaitu 100 $\mathrm{mg} / \mathrm{KgBB}, \quad 200 \mathrm{mg} / \mathrm{KgBB}$ dan 400 $\mathrm{mg} / \mathrm{KgBB}$. Parameter yang diamati adalah kadar asam urat mencit. Hewan uji diinduksi hiperurisemia dengan pemberian suspensi biji melinjo dan jus hati ayam konstrasi $100 \% \mathrm{~b} / \mathrm{v}$ secara oral selama 9 hari berturutturut kemudian diukur kadar asam uratnya (Sukrama, 2015). Setelah hewan uji mengalami hiperurisemia, maka diberikan sediaan pembanding, kontrol positif, dan sediaan uji ekstrak etanol daun Afrika selama 9 hari berturut-turut. Kemudian dilakukan pemeriksaan kadar asam urat darah pada hari ke 1, 3, 6, dan 9. Kadar asam urat diukur dengan menggunakan alat POCT. Kemudian dianalisis secara statistik menggunakan anova dan uji lanjut LSD (Least Significant Difference). Dari data hasil pengukuran kadar asam urat yang didapat kemudian dihitung persentase penurunan kadar asam 
urat dengan rumus $(\% \mathrm{P})$ kadar asam urat (Salsabila et al., 2015).

Persentase penurunan kadar asam urat $=$ $\frac{\text { Kadar asam urat }(-)-\text { kadar asam urat }(\text { uji })}{\text { kadar asam urat }(-)} \times 100 \%$

Keterangan:

Kadar asam urat (uji) $=$ Kadar asam urat kelompok yang diberi perlakukan

Kadar asam urat (-) = Kadar asam urat kelompok kontrol negatif.

Parameter keberhasilan dilihat dari adanya penurunan kadar asam urat dalam darah mencit yang signifikan setelah pemberian sediaan uji terhadap kelompok kontrol negatif.

\section{HASIL DAN PEMBAHASAN}

Penelitian ini diawali dengan pengumpulan sampel tanaman yang digunakan yaitu daun Afrika yang diperoleh dari daerah Pamengpeuk, Garut, Jawa Barat. Setelah sampel tanaman terkumpul, selanjutnya tanaman dideterminasi di Herbarium Bandungense, Sekolah Ilmu dan Teknologi Hayati (SITH) Institut Teknologi Bandung. Determinasi ini bertujuan untuk memastikan identitas tanaman uji dan memastikan bahwa tanaman tersebut benar yang dimaksud dalam penelitian. Hasil determinasi menunjukkan bahwa tanaman tersebut adalah daun Afrika (Vernonia amygdalina Delile.).

Pemeriksaan karakterisasi simplisia dilakukan untuk mengetahui mutu simplisia sebagai jaminan stabilitas dan kualitas dari simplisia yang digunakan harus memenuhi persyaratan yang telah ditetapkan. Pemeriksaan ini meliputi kadar air, susut pengeringan, kadar abu total, kadar abu tidak larut asam, kadar abu larut air, kadar sari larut etanol, dan kadar sari larut air. Standar karakteristik simplisia yang digunakan yaitu mengacu pada standar umum karena tidak didapatkan standar yang menyatakan persyaratan khusus untuk daun Afrika. Hal ini terjadi mungkin dikarenakan tanaman ini merupakan tanaman yang potensi untuk ditelitinya masih sedikit, sehingga belum ada pustaka yang menyatakan standar persyaratan karakteristik daun Afrika.

Penetapan kadar air dilakukan dengan tujuan untuk memberikan batasan minimal atau rentang tentang besarnya kandungan air di dalam bahan. Hal ini dihubungkan dengan kestabilan simplisia selama penyimpanan (Depkes RI, 2000). Penetapan kadar abu dilakukan dengan tujuan untuk memberikan gambaran kandungan mineral internal dan eksternal yang berasal dari proses awal sampai terbentuknya ekstrak. Pada prinsipnya, bahan dipanaskan pada temperatur dimana senyawa organik dan turunannya terdestruksi dan menguap sehingga tinggal unsur mineral dan anorganik (Depkes RI, 2000). Sementara larut air dan etanol dihubungkan dengan kandungan kimia dalam tumbuhan yang terlarut dalam air dan etanol. Penetapan kadar sari dilakukan dengan tujuan untuk memberikan gambaran awal jumlah senyawa kandungan (Depkes RI, 2000).

Tabel 1. Hasil pemeriksaan karakteristik simplisia daun Afrika (Vernonia amygdalina Delile.).

\begin{tabular}{lc}
\hline Pemeriksaan & Hasil $(\boldsymbol{\%})$ \\
\hline Kadar air & 9,95 \\
Susut pengeringan & 9,97 \\
Kadar abu total & 9,50 \\
Kadar abu tidak larut asam & 2,33 \\
Kadar abu larut air & 2,50 \\
Kadar sari larut etanol & 16,90 \\
Kadar sari larut air & 18,22 \\
\hline
\end{tabular}

Penapisan fitokimia dilakukan pada serbuk simplisia dan ekstrak kental. Penapisan fitokimia ini merupakan uji kualitatif yang bertujuan untuk mengetahui kandungan senyawa kimia atau metabolit sekunder yang terdapat dalam tanaman yang diteliti. Hasil ini akan menjadi dasar untuk melakukan pengujian selanjutnya. Penapisan fitokimia pada penelitian ini dilakukan terhadap senyawa golongan flavonoid, saponin, tanin, kuinon, alkaloid, dan steroid/triterpenoid. 
Tabel 2. Hasil penapisan fitokimia simplisia dan ekstrak daun Afrika (Vernonia amygdalina Delile.)

\begin{tabular}{ccc}
\hline $\begin{array}{c}\text { Metabolit } \\
\text { sekunder }\end{array}$ & \multicolumn{2}{c}{ Hasil pengamatan } \\
& Simplisia & Ekstrak \\
\hline Alkaloid & - & - \\
Flavonoid & + & + \\
Saponin & + & + \\
Tanin & + & + \\
Kuinon & + & + \\
Steroid/triterpenoid & + & + \\
\hline Ket: & $(+)=$ Terdeteksi & \\
\multicolumn{2}{c}{$(-)=$ Tidak terdeteksi }
\end{tabular}

Hasil dari penapisan fitokimia menunjukkan bahwa simplisia dan ekstrak daun Afrika mengandung senyawa flavonoid, saponin, tanin, kuinon, dan steroid/triterpenoid (Tabel 2). Tujuan dilakukannya penapisan fitokimia terhadap ekstrak yaitu untuk memastikan bahwa proses ekstraksi serta pemekatan ekstrak tidak merusak senyawa yang terkandung dalam simplisia, dan untuk memastikan bahwa senyawa yang dimaksud dalam pengujian dapat terdeteksi. Flavonoid ini merupakan metabolit sekunder yang diduga dapat berperan sebagai senyawa antioksidan yang terbukti dapat menghambat aktivitas ksantin oksidase (Kristiani et al., 2013).

Metode ekstraksi yang digunakan pada penelitian ini yaitu maserasi. Pelarut yang digunakan yaitu etanol 96\%. Etanol merupakan penyari universal sehingga diharapkan semua senyawa kimia baik polar, semipolar maupun non polar dapat tertarik (Sun et al., 2015). Proses maserasi dilakukan $3 \times 24$ jam, dengan pengadukan sebanyak 2-3 kali sehari dengan tujuan untuk meningkatkan kontak serbuk pada larutan penyari sehingga diperoleh hasil ekstrak kental dengan rendemen ekstrak sebesar $13,93 \%$.

Pengujian aktivitas antihiperurisemia dilakukan terhadap ekstrak etanol daun Afrika dengan menggunakan mencit putih jantan galur Swiss Webster. Dosis yang digunakan dalam penelitian ini menggunakan dosis $100 \mathrm{mg} / \mathrm{KgBB}, 200$ $\mathrm{mg} / \mathrm{KgBB}$, dan $400 \mathrm{mg} / \mathrm{KgBB}$. Pemilihan jenis kelamin jantan didasarkan pada pertimbangan bahwa mencit jantan tidak mempunyai hormon estrogen, jika ada hanya dalam jumlah yang sedikit serta mempunyai kondisi hormonal yang stabil jika dibandingkan dengan mencit betina yang mengalami perubahan hormonal pada masamasa tertentu seperti pada masa siklus estrus, masa kehamilan, dan menyusui dimana kondisi tersebut dapat memengaruhi kondisi psikologis hewan uji (Muhtadi et al., 2014).

Pengukuran kadar asam urat menggunakan metode POCT dengan alat Easy Touch ${ }^{\circledR}$ dimana prinsip analisisnya menggunakan katalis yang digabungkan dengan teknologi biosensor yang spesifik terhadap pengukuran asam urat. Ketika darah diteteskan pada zona strip test maka katalisator asam urat akan mengoksidasi asam urat dalam darah. Intensitas dari elektron yang terbentuk dalam alat setara dengan konsentrasi asam urat dalam darah (Pawestri, 2018). Kadar asam urat awal diukur, selanjutnya mencit dibuat hiperurisemia dengan penginduksian senyawa yang mengandung kadar purin tinggi. Induktor hiperurisemia yang digunakan yaitu suspensi biji melinjo dan jus hati ayam. Pemberian biji melinjo dengan dosis $4 \mathrm{~g} / \mathrm{KgBB}$ dan jus hati ayam 50 $\mathrm{mL} / \mathrm{KgBB}$ selama 9 hari berturut-turut mampu meningkatkan kadar asam urat mencit. Hati ayam dan biji melinjo dipilih karena merupakan jenis makanan yang dapat memicu peningkatan kadar asam urat dalam darah karena mengandung purin dalam kadar yang relatif tinggi. Hati ayam memiliki kandungan purin tinggi yaitu 100-1000 mg purin/ $100 \mathrm{~g}$ bahan makanan sedangkan biji melinjo memiliki kandungan purin sedang yaitu 9-100 mg purin/ $100 \mathrm{~g}$ bahan makanan (Kusumayanti dan Komang, 2014). 
Tabel 3 Rata-Rata Kadar Asam Urat Darah Sebelum Induksi, Saat Terinduksi dan Saat Pemberian sediaan uji

\begin{tabular}{|c|c|c|c|c|c|c|}
\hline \multirow{2}{*}{$\begin{array}{l}\text { Kelompok } \\
\text { Uji } \\
\end{array}$} & \multicolumn{6}{|c|}{ Kadar Asam Urat (mg/dL) } \\
\hline & t0 & Tinduksi & t1 & t3 & t6 & t9 \\
\hline Kontrol (-) & $3,0 \pm 0$ & $7,80 \pm 1,25^{\mathrm{a}}$ & $7,95 \pm 1,16$ & $7,85 \pm 1,2$ & $7,65 \pm 0,89$ & $7,85 \pm 0,80$ \\
\hline Kontrol (+) & $3,0 \pm 0$ & $8,28 \pm 2,31^{\mathrm{a}}$ & $5,98 \pm 1,93$ & $4,8 \pm 2,09 *$ & $3,0 \pm 0,0 *$ & $3,0 \pm 0,0 *$ \\
\hline $\begin{array}{c}\text { Ekstrak } \\
\text { Etanol Daun } \\
\text { Afrika } 100 \\
\text { mg/KgBB }\end{array}$ & $3,0 \pm 0$ & $9,0 \pm 2,31^{\mathrm{a}}$ & $9,05 \pm 0,42$ & $7,95 \pm 0,45$ & $6,63 \pm 0,33$ & $5,25 \pm 1,15^{*}$ \\
\hline $\begin{array}{c}\text { Ekstrak } \\
\text { Etanol Daun } \\
\text { Afrika } 200 \\
\text { mg/KgBB }\end{array}$ & $3,0 \pm 0$ & $9,53 \pm 2,62^{\mathrm{a}}$ & $9,37 \pm 2,94$ & $7,7 \pm 2,43 *$ & $5,57 \pm 1,97 *$ & $4,1 \pm 1.61 *$ \\
\hline $\begin{array}{c}\text { Ekstrak } \\
\text { Etanol Daun } \\
\text { Afrika } 400 \\
\mathrm{mg} / \mathrm{KgBB}\end{array}$ & $3,0 \pm 0$ & $10,4 \pm 2.33^{\mathrm{a}}$ & $9,88 \pm 2,46$ & $7,7 \pm 2,17$ & $4,55 \pm 1,94^{*}$ & $3,45 \pm 0,90 *$ \\
\hline
\end{tabular}

Pada tabel 3 dapat dilihat bahwa ratarata kadar asam urat sebelum induksi rendah yaitu 3,0 $\mathrm{mg} / \mathrm{dL}$ dikarenakan belum terjadi hiperurisemia, sedangkan rata-rata kadar asam urat mencit dari semua kelompok setelah diinduksi mengalami perbedaan yang bermakna secara statistik dibandingkan dengan nilai awal sebelum induksi. Hal tersebut dapat dinyatakan semua hewan uji mengalami hiperurisemia, ini menunjukkan bahwa pemberian kombinasi biji melinjo dan hati ayam efektif dalam meningkatkan kadar asam urat darah. Pada kelompok kontrol positif terjadi penurunan mulai hari ke-3 hingga hari ke-9 pengujian. Hal ini menunjukkan bahwa metode induksi dan metode pengujian telah valid, sementara ekstrak etanol daun Afrika mampu menurunkan kadar asam urat mencit yang berbeda bermakna secara statistik mulai pada hari ke-6 untuk dosis $200 \mathrm{mg} / \mathrm{kgBB}$ dan 400 $\mathrm{mg} / \mathrm{KgBB}$ yang terus belangsung hingga pengujian pada hari ke-9 dan pada kelompok dosis $100 \mathrm{mg} / \mathrm{kgBB}$ baru menunjukkan penurunan pada hari ke-9. Hal ini menunjukkan bahwa efek antihiperurisemia berkaitan dengan dosis ekstrak yang diberikan (Rahmi et al., 2020). Selain itu, dosis $100 \mathrm{mg} / \mathrm{KgBB}$ dalam menurunkan kadar asam urat membutuhkan waktu lebih lama juga terjadi karena kandungan senyawa aktif atau metabolit sekunder yang terdapat dalam ekstrak etanol daun Afrika dosis 100 $\mathrm{mg} / \mathrm{KgBB}$ lebih sedikit dibandingkan dengan dosis 200 dan $400 \mathrm{mg} / \mathrm{KgBB}$ (Alara et al., 2020).

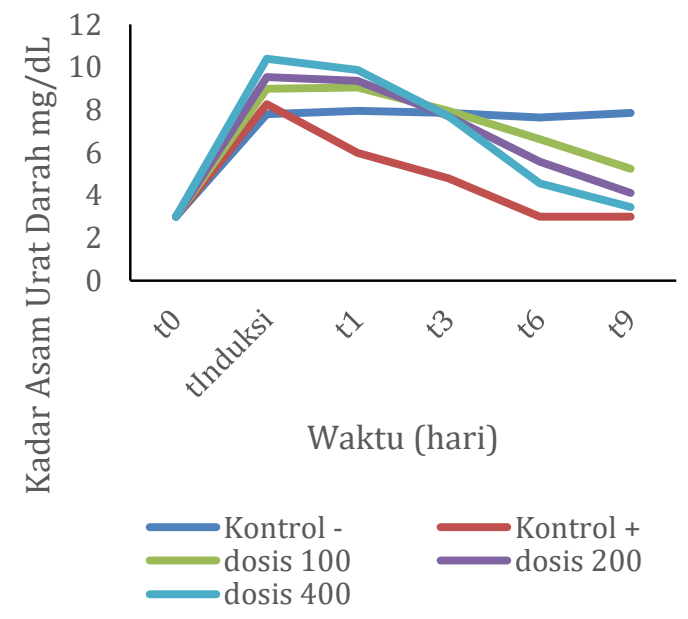

Gambar 1. Grafik rata-rata kadar asam urat pada mencit yang diberi perlakuan ekstrak etanol daun Afrika pada berbagai dosis 


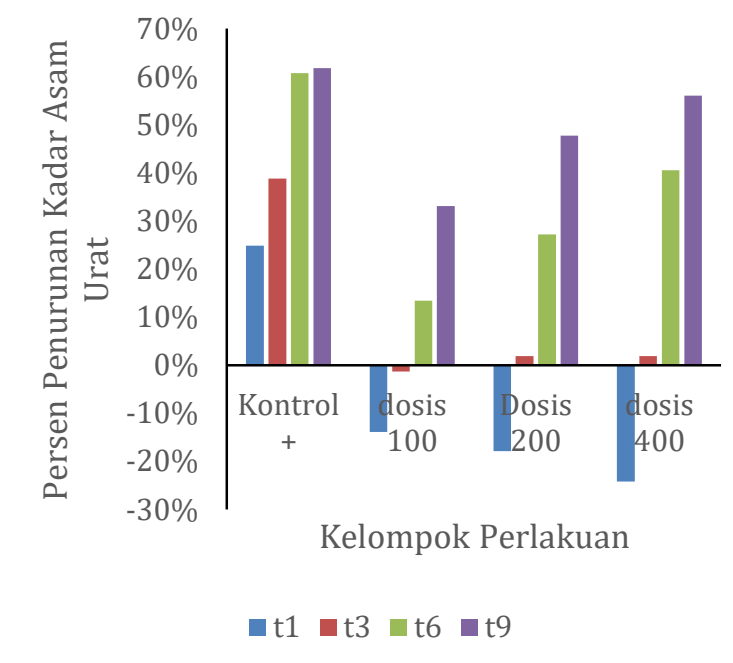

Gambar 2. Grafik persentase penurunan asam urat setelah diberikan perlakukan ekstrak etanol daun Afrika

Pada Gambar 1 dapat dilihat bahwa terjadi peningkatan kadar asam urat darah dari t0 ke $\mathrm{t}$ induksi yang menandakan bahwa hewan uji berhasil terinduksi. Kemudian terjadi penurunan pada hari ke-9 pada kelompok kontrol positif, kelompok perlakukan ekstrak etanol daun Afrika dosis $100,200,400 \mathrm{mg} / \mathrm{KgBB}$ yang sejalan dengan hasil statistik yang menunjukkan kebermaknaan jika dibandingkan terhadap kontrol negatif dimana dapat dikatakan bawa semua dosis uji memiliki efek sebagai antihiperurisemia. Selain itu, kelompok kontrol negatif menunjukkan masih dalam kondisi terinduksi hingga akhir pengujian yang menunjukkan permodelan hewan uji berhasil dilakukan.

Aktivitas antihiperurisemia yang ditunjukkan oleh alopurinol maupun ekstrak etanol daun Afrika dengan dosis 100, 200, dan $400 \mathrm{mg} / \mathrm{KgBB}$ dinyatakan juga dalam persen penurunan kadar asam urat. Hasilnya dapat dilihat pada gambar 2 dimana persen penurunan tertinggi sebesar $62 \%$ pada hari ke-9 ditunjukkan oleh alopurinol dibandingkan dengan semua dosis ekstrak. Hal ini berkaitan dengan alopurinol yang telah dinyatakan sebagai standar terapi untuk hiperurisemia dan gout (Becker et al., 2015). Alopurinol merupakan salah satu urikostatik yang saat ini digunakan secara terapeutik dimana bekerja dengan mengurangi pembentukan asam urat dengan menghambat ksantin oksidase dan asam urat dimana dalam dosis rendah mekanisme penghambatan berlangsung secara kompetitif dan dalam dosis tinggi bekerja secara tidak kompetitif, melalui penghambatan ksantin oksidase maka hipoksantin dan ksantin diekskresi lebih banyak dalam urin sehingga kadar asam urat dalam darah dan urin menurun (Chen et al., 2014). Sementara pada ekstrak persen penurunan tertinggi sebesar $56 \%$ ditunjukkan oleh dosis $400 \mathrm{mg} / \mathrm{kgBB}$ pada hari ke-9 juga. Mekanisme kerja ekstrak etanol daun Afrika belum diketahui secara pasti. Namun flavonoid yang terkandung di ekstrak etanol daun Afrika diduga berperan dalam menurunkan kadar asam urat karena bersifat antioksidan dan dapat menghambat aktivitas enzim ksantin oksidase (Lin et al., 2015). Selain itu, saponin juga diduga berperan dalam menurunkan kadar asam urat dengan bekerja mengurangi aktivitas enzim ksantin oksidase dalam serum. Sedangkan senyawa tanin diduga dapat mengikat radikal bebas selama perubahan purin menjadi asam urat (Rakanita et al., 2017).

\section{KESIMPULAN}

Dari hasil penelitian dapat disimpulkan bahwa ekstrak etanol daun Afrika (Vernonia amygdalina Delile.) dosis 100, 200, dan $400 \mathrm{mg} / \mathrm{KgBB}$ memiliki aktivitas antihiperurisemia yang diinduksi oleh melinjo dan jus hati ayam dengan persentase penurunan kadar asam urat terbesar ditunjukkan oleh ekstrak etanol daun Afrika dosis $400 \mathrm{mg} / \mathrm{KgBB}$ sebesar $56 \%$ namun masih lebih rendah dibandingkan dengan kemampuan alopurinol.

\section{UCAPAN TERIMA KASIH}

Ucapan terimakasih kepada Kementerian Riset dan Teknologi serta Fakultas MIPA Universitas Garut yang telah mendanai penelitian ini. 


\section{Daftar Pustaka}

Alara, O.R., Abdurahman, N.H. and Olalere, O.A., 2020. Ethanolic extraction of flavonoids, phenolics and antioxidant from Vernonia amygdalina leaf using two-level factorial design. Journal of King Saud University-Science, 32(1), pp.7-16.

Becker, M.A., Patrick, F.D., Choi, H.K., Dalbeth, N., Storgard, C., Cravets, M. and Scott, B., 2015. An Open-label, 6-month study of allopurinol safety in gout: The LASSO study. Seminars in Arthritis and Rheumatism, 45(2), pp.174-183.

Chen, Y.C., Huang, C.C., Tsai, K.C., Huang, W.J., Huang, W.C., Hsu, Y.C. and Hsu, F.L., 2014. Evaluation of the antihyperuricemic activity of phytochemicals from Davalia farmosana by enzyme Assay and hyperurecemic mice model. Hindawi Publishing Corporation Evidence-Based Complementary and Alternative Medicine, vol 2014, http://dx.doi.org/10.1155/2014/873607

Departemen Kesehatan Republik Indonesia, 2000. Parameter standar umum ekstrak tumbuhan obat cetakan pertama (pp.13-32). Jakarta.

Djohar, M. and Paramitha, R., 2015. Efektivitas rebusan daun salam (Syzygium polyanthum) terhadap penurunan kadar asam urat dalam darah mencit putih jantan. Pharmacy, 12(2), pp.176-185.

Kementerian Kesehatan Republik Indonesia. 2018. Hasil Utama Riskesdas 2018.

Kristiani, R. D., Rahayu, D. and Subarnas, A., 2013. Aktivitas antihiperurisemia ekstrak etanol daun pakis tangkur (Polypodium feei) pada mencit jantan. New Bionatura, 15(3), pp.174-177.

Kusumayanti, G.A.D., Wiardani, N.K. and Sugiani, P.P.S., 2014. Diet mencegah dan mengatasi gangguan asam urat. Jurnal Ilmu Gizi, 5(1), pp.69-78.

Muhtadi, Suhendi, A., Wahyuningtyas, N., and Sutrisna, E.M., 2014. Uji praklinik antihiperurisemia secara in vivo pada mencit putih jantan galur balb-c dari ekstrak daun salam (Syzigium polyanthum walp) dan daun belimbing wuluh (Averrhoa bilimbi 1.). Biomedika vol 6(1); 17-23.

Pawestri, U., 2018. Aktivitas antihiperurisemia ekstrak etanol daun kesum (Polygonum minus Huds.) pada mencit jantan galur swiss webster. Skripsi S1 Prodi Farmasi Universitas Garut.

Rahmi, E.P., Kumolosasi, E., Jalil J., Husain, K., Buang, F., Razak, A.F.A. and Jamal, J.A., 2020. Anti-hyperuricemic and anti-inflammatory effects of Marantodes pumilum as potential treatment for gout. Front. Pharmacol, 11. doi: 10.3389/fphar.2020.00289

Rakanita, Y., Hastuti, L., Tandi, J. and Mulayani, S., 2017. Efektivitas antihiperurisemia ekstrak etanol daun seledri (eeds) pada tikus induksi kalium oksonat. Journal of Tropical Pharmacy and Chemistry, 4(1), pp.1-6.

Sinaga, A. F., Bodhi, W. and Lolo, W.A., 2014. Uji efek ekstrak etanol daun salam (Syzygium polyanthum (Wight.) Walp) terhadap penurunan kadar asam urat tikus putih diinduksi potasium oksonat. Pharmacon Jurnal Ilmiah Farmasi, 3(2), pp.141-145.

Sukrama, I.D.M., 2015. Xanthine oxydase inhibition of kombucha tea in hyperuricemia induced wistar rat: decrease of uric acid, malondialdehyde, and 8-hydroxy-2'deoxyguanosine. Bali Medical Journal, 4(1), pp.32-36.

Sumarmin, R., Yuniarti, E., and Zulino, G., 2017. Uji in vivo ekstrak buah mahkota dewa (Phaleria macrocarpa (Scheff.) Boerl.) terhadap kadar asam urat pada mencit jantan (Mus musculus L.). Journal Biosains, 1(2), pp.57-61. 
Sun, C., Wu, Z., Wang, Z. and Zhang, H., 2015. Effect of ethanol/water solvent on phenolic profiles and antioxidant properties of beijing propolis extracts. Hindawi Publishing Corporation Evidence-Based Complementary and Alternative Medicine, Vol 2015 http://dx.doi.org/10.1155/2015/595393

Tarigan, I. M., Bahri, S. and Saragih, A., 2012. Aktivitas antihiperurisemia ekstrak etanol herba suruhan (Peperomia pellucida (L.) Kunth) pada mencit jantan. Journal of Pharmaceutics and Pharmacology, 1(1), pp.37-43. 